\title{
Polychromatophilic Normoblast Count
}

National Cancer Institute

\section{Source}

National Cancer Institute. Polychromatophilic Normoblast Count. NCI Thesaurus. Code C147419.

The determination of the amount of polychromatophilic normoblasts present in a sample from an experimental organism. 